\title{
LOCAL CURRENCY SYSTEMS IN GERMAN-SPEAKING COUNTRIES - SELECTED ISSUES
}

\author{
Patrycja Konieczna ${ }^{128}$ \\ https://doi.org/10.31410/itema.2018.315
}

\begin{abstract}
Alternative currencies, including local currencies, have recently gained enormous popularity. The oldest local currency is the Austrian currency Wörgl, created in 1932, the main feature of which was the loss of value by $1 \%$ in the absence of its use. Unfortunately, the Central Bank of Austria closed the project a year later; however, the rise of Wörgl gave an impulse to create more local currency systems. In 1934, the WIR project was launched in Switzerland (from German "we"), it is the oldest local currency still functioning today. Currently, there are about 5,000 local currencies of various types around the world, and new ones are constantly arriving, but this article will examine, due to their specificity, only local currency systems in German-speaking countries.

The purpose of this paper is to identify the similarities and differences between selected local currencies in German-speaking regions. The functioning of local currency systems, prerequisites for the creation of such systems and causes for the fall of some of them will be analyzed. The author will identify the reasons for impulses to create local currencies in these regions and will look for the answer to the question: "Why did local currencies appear in the German-speaking countries as one of the first in the world?".

The territorial range includes the following countries: Germany, Austria, Switzerland and Luxembourg. The time range will cover the years 1932-2017. The subject of research will be selected systems of local currencies. The article is a descriptive analysis based on studies of mainly English-language literature, Community Currencies in Action (CCIA) reports, selected local currencies websites, and financial law studies. The comparative method was used to examine the similarities and differences in the functioning of local currencies in Germanspeaking countries.

The conducted research has shown that local currencies largely support the development of regions, encourage entrepreneurship and strengthen the position of enterprises, mainly the SME sector. Local currency systems do not only affect the local market, but also have an influence on the development of the economy of the whole country. The research shows that local currencies have become the simplest chance for selected regions to reduce unemployment, increase investment attractiveness, and sometimes even eliminate social unrest and petty crime.
\end{abstract}

Keywords: financial market, money, local currencies

\section{INTRODUCTION}

I n 1932, when first local currency Wörgl appeared, nobody assumed that it may initiate occurrence of similar ventures all over the world, which will be a real alternative for the traditional money. The idea of local currency, in spite of simplicity of use, may turn out to be the most efficient way of development of local community. The aim of the study is characteristics and analysis of selected local currencies in German-speaking countries, where several dozen of such currencies are functioning. These countries can be seen as pioneers in

\footnotetext{
${ }^{128}$ Wrocław University of Economics, ul. Nowowiejska 3, 58-500 Jelenia Góra, Poland
} 
implementation of local currencies systems. It is accepted, that the first local currency in the world occurred in 1932 in Austria. However, Swiss currency WIR has been functioning continuously since 1934 as the oldest local currency which is still in use. It is also worth paying attention to Regiogeld system, created in Germany, which gathers local currencies of Germanspeaking countries. Regiogeld system, as unique in Europe, provides support to creators of local currencies and users of the currencies.

Territorial scope of the study covers such countries as: Germany, Austria, Switzerland and Luxembourg. The temporal scope spans years $1932-2017$ and the subject of studies is selected systems of local currencies. The article has a character of descriptive analysis which was conducted based on studies of Polish, English and German literature, publications of Community Currencies in Action (CCIA), the websites of selected local currencies and studies in the field of financial law. A comparative analysis method was used in order to examine similarities and differences in functioning of local currencies in German-speaking countries.

\section{THE IDEA OF LOCAL CURRENCIES}

Local currencies are subgroup of alternative currencies whose functions can be described best as „conventional tender of a certain social group”. Therefore, local currencies are an alternative to money traditionally used in a given country [1]. The idea of application of local currency as an attractive way of the local development, especially of small and medium-sized enterprises, which is implemented since less than a hundred years. The concept of alternative currency is closely linked to notion of social economy and constitutes ,the core" of the development of local communities. Local currencies occur mainly in developed countries. In western Europe communities involved in social entrepreneurship very often appoint and create local currencies [2].

Local currencies can be material or in a form of IT record as virtual money (cryptocurrency). They are not supported and are not subject to interference by governmental authorities or central bank. The advantages of systems of these currencies are lack of inflation and low maintenance costs [3]. Local currencies are not transferred outside the region where they are functioning, but they increase the local market. The currency supports local businesses by generating local trading, so it functions as a catalyst of local entrepreneurship and integrates the community of the region. Their greatest benefit is involving capital on a given area, reducing the problem of gridlock and preventing situations from speculations which distort the idea of traditional money [4].

Among about 6000 currencies, local monetary systems dominate - social currencies $(80-90 \%)$ [5]. The marketing of the local currencies is promoted by Community Currencies in Action (CCIA), partially funded by European Union, which supports existing systems of local currencies and helps to implement new pilot currencies on the market. As at May 2015 CCIA kept 6 programmes of pilot currencies: SoNantes in France inspired by Swiss WIR, Makkie and TradeQoin in Netherlands, E-Portemonnee in Belgium, Brixton $£$ in Lambeth and Spice Timebanks in Great Britain [6]. 


\section{SELECTED LOCAL CURRENCIES OF GERMAN-SPEAKING COUNTRIES}

In Austria, Wörgl - the currency named after the town and created in 1932, is a pioneer of local currencies. The mayor Michael Unterguggenberger who took into consideration rising unemployment and deepening global crisis, decided to use the concept of Silvio Gesell, an economist, and issued Wörgl shilling, which was exchanged at hard peg 1:1 into schilling issued by the Central Bank of Austria [7]. The owner of an alternative currency had to go for a stamp to the office every month and pay $1 \%$ of its nominal value. Silvio Gesell called this fee a demurrage tax (also called negative yields). The essence of demurrage is mandatory fee for downtime of money which should encourage to spend money. In case of Wörgl it enforced 13 times faster money turnover than turnover of Austrian schilling in economy [3]. As a result, unemployment fell over in few months and economic situation improved significantly (many jobs appeared, poverty fell, the town made planned investments, new residential buildings were built as well as ski jump) [7]. Unfortunately, the Central Bank of Austria closed the project after a year, thus poverty came back to the town. Nevertheless, Austrian Wörgl became a pioneer of systems of local currencies worldwide.

In Switzerland local currency WIR was created. It was inspired by Austrian Wörgl and is considered to be the oldest local currency which is still in use. WIR is an abbreviation for „Wirtschaftsring” (from German language „economic cycle”) but also „Wir” (from German language „we") [8]. This local currency is mainly involved in support of small and mediumsized enterprises of the construction, building, manufacturing and hotel sectors. WIR has been functioning continuously since 1934 and has complete cover in tangible assets (it is created against the assets) [9]. The members of this system may take out interest-free credits [3]. Since 2004 WIR franc has been registered as currency and is functioning parallel to Swiss franc, while in 2005 the Swiss uttered WIR Euro as third national currency. Since 2013 WIR has had over 60000 users: 45000 SMEs and 15000 entrepreneurs and shareholders [8]. In 2013 WIR organized about $17 \%$ local business of Switzerland and it is estimated that by the end of 2018 it will be about 20\%. In 2017 WIR Bank recorded profits of about CHF 15 million, while its assets amounted over CHF 5 trillion with about CHW (WIR Swiss franc) 1 trillion [10].

In Luxembourg, local currency was introduced by Mayor Camille Gira and project coordinator Max Hilbert. The currency named Beki was introduced at the end of 2012 in Redange canton [11]. The currency is converted into euro 1:1 and was mainly designed from the need to move canton towards environmental sustainability and support of small and medium-sized enterprises what, on the assumption, will enhance autonomy of the region [12]. In order to use the currency, businesses and private citizens have to be „De Kar” members - organization which manages Beki local currency. Although the currency is completely convertible to euro, the consumers, in order to exchange Beki back to conventional currency, have to pay handling fee of 5\% (it ensures income for further functioning of the currency and additionally encourages expenses in local currency instead of euro) [11]. At the beginning of 2016500000 euros were converted to Beki currency and number of consumers reached almost 100 companies and associations. A great proponent of Beki is local shopping mall PALL in Oberpallen with about 20 shops, restaurants and providers accepting local currency Beki. Also, farms selling organic vegetables, local bakers and EIDA (local environmentally-friendly power station) are consumers of this currency. Some consumers accepted even 20000 Beki on single invoice [13]. Beki currency belongs to German network of local currencies (Regiogeld), which is presented in Figure 1. 


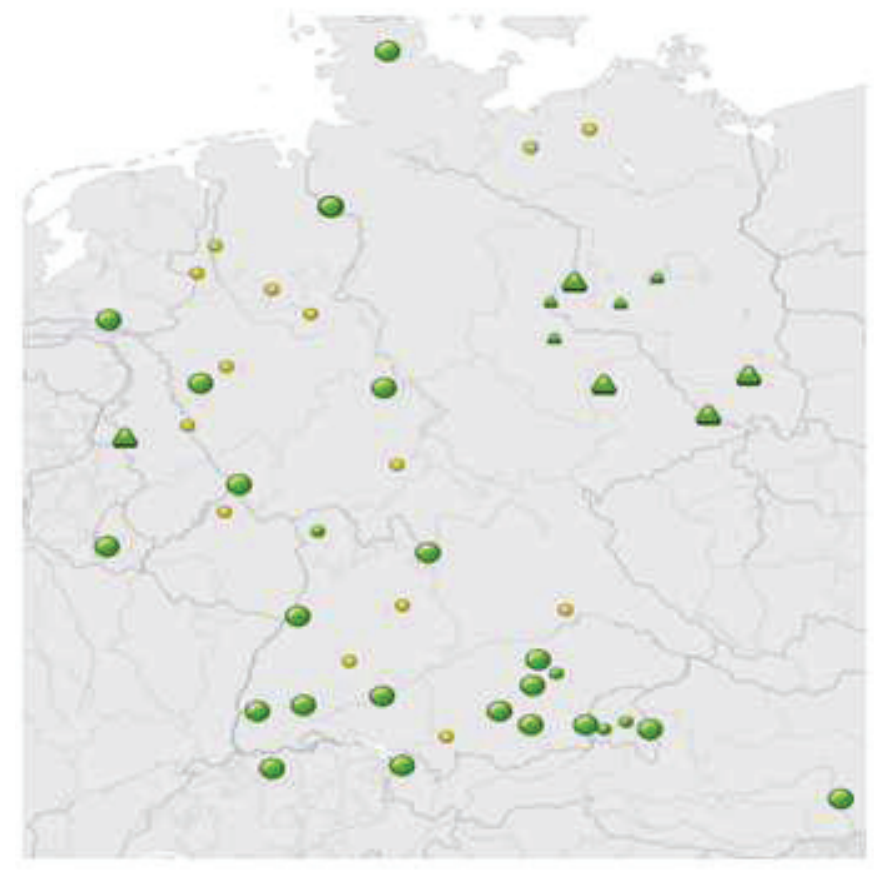

green point -
an issuer of regional money with
deposit in euro

green triangle -

an issuer of regional money covered by commodities and services

yellow point -

a group which explores and developes local distribution of regional money

Figure 1: The members of Regiogeld network

Germany is a country where several local currencies are functioning (there are 46 as on 2016), some of them belong to Regiogeld network (Fig.1.). Regiogeld brings together local currencies of Germany (Chiemgauer, Havelblüte, Elbtaler, Vorarlberger Talente and others - together 28), Luxembourg (Beki), Switzerland (Tallent) and Austria (STYRRION) [14]. The organization provides professional assistance for regions which decided to implement alternative currency. On its website, the organization updates a map of local currencies, also advises and arranges trainings and conferences. The idea of Regiogeld is to complement national currency by regional money [15]. Association in Regiogeld is to promote economies in order to increase welfare in regions by [16]:

- merger purchasing power of regions by promoting regional businesses and stimulating regional economic cycles,

- support in selling regional products, generating new revenues and creating new jobs,

- help in shortening transport routes and hence, promoting environmentally friendly way of running the business.

Chiemgauer local currency, created in 2003 in Prien am Chiemsee in Bavaria (in Germany), also belongs to Regiogeld network. The creator of the project was an academic staff Christian Gelleri who launched Chiemgauer currency together with students [17]. Preserving the movement of banknote requires payment from the owner once in every three months in form of demurrage tax. The proponents of the system estimate, that Chiemgauer circulates in cycle 2.5 times faster than euro. The entrepreneurs who take part in the programme pay 100 euros once and pay a monthly sum of 5 to 10 euros (depending on trading), moreover exchange Chiemgauer to euro requires to pay $5 \%$ commission by the entrepreneur [18]. The good point is the possibility of taking out a micro-credit in this local currency. Chiemgauer also supports non-profit organizations, which buy 100 Chiemgauers for 97 euros and sell for 100 euros, gaining 3\% for their own prosperity [19]. In 2003 EUR 68286 was exchanged to new currency and in 2012 it was EUR 1864 463. The turnover reached 5.1 million euros. In 2010 it was disbursed micro-credit of 20000 Chiemgauers. From April 2010 to December 2011275 credits were granted. In May 2013 it was possible to pay in local currency 567 entrepreneurs from such sectors as catering, supermarkets, car workshops and hotels [2]. The success of Chiemgauer led 
objectives and targets. Some currencies, for instance German Chiemgauer, support local nonprofit organizations, which by buying and selling local currency may gain 3\% of its initial value. Other currencies support sector of small and medium-sized enterprises and sustainable development of region. The majority of local currencies systems have been functioning continuously since their creations (Austrian WIR has been developing for 86 years), but some of them had to be closed because of unfavorable legal measures in a given country (as in the case of Austrian Wörgl). Undoubtedly the aim of all local currencies was to achieve higher turnover than circulation of traditional money. This aim was fulfilled by demurrage tax, commissions, handling fees or fees dependent on trading.

A virtue is belonging of studied currencies to Regiogeld system (Beki, Chiemgauer) which supports initiatives of creating systems of local currencies. Although WIR does not belong to Regiogeld, it attempts to create own currency network covering whole Switzerland, what must be also considered to be a positive phenomenon which supports economic development of the country. Unfortunately, majority of German-speaking countries misses precise legal measures concerning local currencies systems. German Bundesbank tolerates regional currencies considering that they are not traditional money or any other financial instrument (similarly in Luxembourg and Austria). German local currencies are called coupons and they can be used by member of one of associations operating in particular system of alternative currencies. However, in Switzerland financial law might be considered as favorable (as it accepts WIR Franc and WIR Euro simultaneously with Swiss franc WIR and WIR Euro).

\section{SUMMARY}

A great opportunity for areas relegated socially and economically with high unemployment rate, are alternative currencies. Even if there is openness to changes in these areas, it is lack of one important thing - money. When it appears (for instance in form of Union Funds) it disappears quickly because of orders for companies outside the region or spending in foreign discount stores. In regions suffering from lack of cash, it may be useful to introduce local currency. In German-speaking countries it meant improvement of development prospects: unemployment started to fall, local prosperity was improving and as a consequence it activated and developed the region. The efficiency of local currencies is due to the fact that using their results in keeping money in local turnover, which generates the growth of monetary transactions in local communities, and this has a positive effect on economic growth (buy mainly local products in local businesses by consumers of local currencies).

Systems of local currencies in German-speaking countries are created in order to reduce social exclusion, unemployment and poverty. Thereby contributing to integrating the local community, by increasing wellbeing, they create a new look at the chances of development of the region. Globalization, digitization, continuous threat of a crisis and deepening social inequalities, growing areas of poverty and unemployment, political conflicts, corruption and social unrests obviously support the formation of this kind of initiatives. Existing systems of local currencies do not compete with official currencies as it is not their objective.

Future functioning of local currencies is unknown but still growing and mounting problems of socio-economic nature and parallel development of communication technologies may lead to situation in which 21 st century will become a century of development of many alternative currencies. 


\section{REFERENCES}

[1] Kurek R. (2014) Alternatywne waluty wirtualne [Alternative virtual currencies], Annales Universitatis Mariae Curie-Skłodowska. Sectio H, Oeconomia, Lublin;

[2] Szeszko P. (2013) Alternatywne waluty narzędziem wspierajacym ekonomie społeczna [Alternative currencies a tool supporting the social economy], Fundacja Inicjatyw Społeczno-Ekonomicznych, Warsaw;

[3] Mazurek A. (2017) Waluty lokalne. Nie tylko sposób na niespokojne czasy [Local currencies. Not just a way to restless times], CXO, Warsaw;

[4] Maroszek W. (2015) Alternatywa dla pieniędzy. Po co wprowadza się lokalne waluty? [Alternative for the money. Why introduce local currencies?], Redakcja Forebes, Warsaw;

[5] Ed. Sobiecki R. (2015) Przeciwdziałanie turbulencjom $w$ gospodarce [Counteracting turbulences in the economy], Oficyna Wydawnicza Szkoła Główna Handlowa w Warszawie, Warsaw, pp. 68;

[6] Community Currencies in Action, http://communitycurrenciesinaction.eu/flyer/, [accessed: 22-10-2018];

[7] Brzozowiec D. (2012), Cud w mieście Wörg [A miracle in the city of Wörgl], Nowoczesny Bank Spółdzielczy, nr 7-8, pp. 52-54;

[8] Community Currency Knowledge Gateway, WIR Bank, http://communitycurrency.info/en/currencies/wir-bank/, [accessed: 29-10-2018];

[9] Kennedy M. (2004) Pieniądz wolny od inflacji i odsetek [Money free of inflation and interest], Wydawnictwo "Zielone Brygady", Cracow, pp. 113-114;

[10] WIR Bank, Selected items of the balance sheet and profit and loss account in 2017, https://www.wir.ch/ueber-uns/investor-relations/kennzahlen/\#eintrag-5541, [accessed: 2210-2018];

[11] Community Currency Knowledge Gateway, Beki, http://communitycurrency.info/en/currencies/beki/, [access: 22-10-2018];

[12] Beki, Funktionnement, https://www.beki.lu/beki/funktionnement, [accessed: 22-10-2018];

[13]Luxembourg Times, The Beki celebrates half million in circulation, https://luxtimes.lu/archives/6692-the-beki-celebrates-half-million-in-circulation, [accessed: 29-10-2018];

[14] Regiogeld, Mitglieder, https://regionetzwerk.blogspot.com/p/karte.html, [accessed: 26-102018];

[15]Regiogeld, Aktuelle Regiogeld-Initiativen, http://regiogeld.com/aktuelle-regiogeldinitiativen/, [access: 26-10-2018];

[16]Rost N. (2007) Regionales Wirtschaften als Ergänzung zur Globalisierung [Regional Economy Systems as Complement to Globalization], Zeitschrift Humanwirtschaft, number 02/2007;

[17]Klawitter N. (2007) Germany's Local Currencies: Economic Cure or Fool's Gold? Spiegel, Hamburg;

[18]Chiemgauer, Chiemgauer in der Praxis, https://www.chiemgauer.info/fileadmin/user_upload/Basisinfo/Chiemgauer_praktisch.pdf [accessed: 26-10-2018];

[19]Community Currency Knowledge Gateway, Chiemgauer, http://communitycurrency.info/en/currencies/chiemgauer/, [accessed: 22-10-2018];

[20]Polonika, Dokad po pomoc? http://www.polonika.at/index.php/poradnik/poradyprawne/1262-dokad-po-pomoc, [accessed: 22-10-2018] 